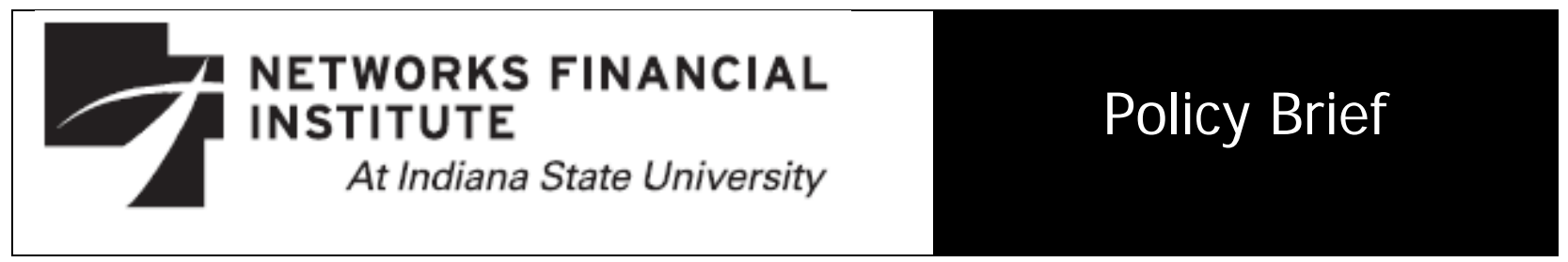

2011-PB-01

March 2011

\title{
Insurance Regulation and the Dodd-Frank Act
}

\section{Scott E. Harrington}

Abstract: This paper discusses a number of key issues regarding implementation by the Financial Stability Oversight Council (FSOC) and the Federal Insurance Office (FIO) of the Dodd-Frank Act's provisions affecting insurance. The paper emphasizes the fundamental differences between insurance and banking, including much lower potential for systemic risk and substantial market discipline in insurance, and how those differences favor solvency regulation and guaranty systems that reflect the distinctive features of each sector. The FSOC and FIO should carefully consider those differences in their analyses of possibly systemically important insurance companies and in the FIO's study and report to Congress on insurance regulation. Particular attention should be paid to the relatively low systemic risk and relatively strong market discipline in insurance compared with banking.

About the Author: Scott E. Harrington, Ph.D. is the Alan B. Miller Professor in the Health Care Management and Insurance and Risk Management departments at the Wharton School, University of Pennsylvania. He is an adjunct scholar at the American Enterprise Institute. A former President of both the American Risk and Insurance Association and the Risk Theory Society, he is a Co-Editor of the Journal of Risk and Insurance and has published widely on the economics and regulation of insurance. A frequent speaker on insurance markets, regulation, and public policy, he has conducted research, consulted, or served as an expert for many organizations. He has testified before the U.S. House and Senate and before numerous U.S. state legislative and administrative committees. He currently teaches classes on health care financial management, health policy, and healthcare econometrics.

\footnotetext{
This policy brief was prepared for the Networks Financial Institute $7^{\text {th }}$ Annual Insurance Reform Summit. The views expressed are those of the individual author and do not necessarily reflect official positions of Networks Financial Institute. Any errors or omissions are the responsibility of the author. Please address questions regarding content to Scott Harrington at harring@wharton.upenn.edu, or visit his website at www.scottharringtonphd.com. NFI working papers and other publications are available on NFI's website (www.networksfinancialinstitute.org). Click "Thought Leadership" and then "Publications/Papers."
} 


\section{Insurance Regulation and the Dodd-Frank Act Introduction}

The Dodd-Frank Wall Street Reform and Consumer Protection Act could have farreaching effects on insurance regulation. The Act created the Financial Stability Oversight Council (FSOC) to oversee systemic risk, with the authority to identify systemically significant "nonbank financial companies," including insurance companies, which will be subject to heightened supervision by the Federal Reserve Board. It also created the Federal Insurance Office (FIO) within the Department of Treasury to monitor all aspects of the insurance industry and negotiate and enter into international agreements concerning prudential matters for insurance and reinsurance.

The financial crisis, American International Group (AIG) bailout, and enactment of the Dodd-Frank Act have fundamentally altered the debate over insurance regulatory modernization. Prior to the crisis, much of the debate over insurance regulation focused on state modernization efforts regarding regulation of rates, policy forms, and market conduct, and on whether optional federal chartering and regulation was desirable to improve regulatory efficiency on those dimensions. The new focus is on systemic risk, solvency, and how implementation of the Dodd-Frank Act will affect the insurance sector and the structure and locus of insurance regulation. As the implementation of the Act evolves, the National Association of Insurance Commissioners (NAIC) is exploring key issues in solvency regulation and supervision through its Solvency Modernization Initiative, including core principles, group solvency, capital requirements, corporate governance, international reinsurance transactions, and international accounting and regulatory standards.

This paper discusses a number of key issues regarding implementation by the FSOC and FIO of the Dodd-Frank Act's provisions affecting insurance. ${ }^{1}$ Despite some convergence, U.S. financial institutions can be expected to specialize predominantly in either banking (and/or securities) or insurance for the foreseeable future. The paper emphasizes fundamental differences between insurance and banking, including low potential for systemic

\footnotetext{
${ }^{1}$ Parts of this paper draw from my September 2009 NAMIC Issue Brief, The Financial Crisis, Systematic Risk, and the Future of Insurance Regulation (edited version published as an invited article in the Journal of Risk and Insurance 76 (December 2009): 785-819).
} 
risk and strong market discipline in insurance, and how those differences favor regulatory and guaranty systems that reflect the distinctive features of each sector. The FSOC and FIO should carefully consider those differences in their analyses of possibly systemically important insurance companies and in the FIO's study and report to Congress on insurance regulation. Particular attention should be paid to the relatively low systemic risk and relatively strong market discipline in insurance compared with banking.

The next section summarizes the insurance sector's role in the financial crisis and the extent to which insurance poses systemic risk. Following this background, the paper first considers possible FSOC designation of one or more insurance entities as systemically significant and potential consequences of such designation. It then considers the role of the $\mathrm{FIO}$ and a number of key factors that should influence its required study and report to the Congress on insurance regulation, as well as its future negotiation of international agreements related to insurance and reinsurance solvency supervision.

\section{The Financial Crisis, AIG, and Systemic Risk}

Prior to the financial crisis, many banks, investment banks, thrifts, hedge funds, mortgage originators, and subprime borrowers took on substantial risk in anticipation of continued housing price appreciation. If housing prices had continued to climb, or at least not fall, they would have achieved large returns. If housing prices fell, much of the losses would be borne by others. Implicit or explicit guarantees of debt issued by Fannie Mae and Freddie Mac lowered financing costs and contributed to the housing bubble in general and rapid expansion of subprime lending in particular. Deposit insurance and implicit guarantees of banks' obligations likewise encouraged risky lending, especially as the Congress pressed them, Fannie Mae, and Freddie Mac to expand lending to low-income borrowers.

Some banks located their leveraged investments in opaque, off-balance sheet vehicles. Investment banks helped spread the risk of housing price declines and mortgage defaults broadly through securitization. The change of ownership from partnerships to corporate ownership very likely encouraged major investment banks to take on more risk in relation to capital, especially in view of the expanded competition with investment bank affiliates of bank holding companies. The Security and Exchange Commission's adoption in 
2004 of consolidated supervision of the major investment banks allowed them to substantially increase their leverage and take on more subprime exposure. Subprime mortgage originators were largely new entrants with little reputational capital at jeopardy and only modest participation in the risk of underlying mortgages. In conjunction with widespread speculation, the Federal Reserve kept short-term interest rates at historically low levels, fueling demand for credit and housing, and encouraging relaxation in historical underwriting standards. Regulators uniformly failed to anticipate the coming crisis.

\section{AIG and its Bailout}

The financial collapse and U.S. government bailout of American International Group immediately following the bankruptcy of Lehman Brothers in September 2008 stunned the financial world. The initial $\$ 85$ billion assistance package was repeatedly modified, with total federal commitments to provide assistance growing to $\$ 182$ billion and assistance outstanding of approximately $\$ 132$ billion as of May, 2010. During 2008, approximately \$21 billion of assistance was provided to support AIG's domestic ( $\$ 17$ billion) and foreign (\$4 billion) life insurance subsidiaries, largely to offset losses associated with securities lending. ${ }^{2}$ The bulk of the remaining assistance went to AIG to meet asset and liquidity needs posed by losses to bank and investment bank counterparties because of AIG's credit default swap and securities lending transactions.

Although securities lending activities associated with AIG's life insurance subsidiaries contributed to significant problems and collateral calls, the original government assistance was precipitated by a liquidity crisis resulting largely from these AIG non-insurance activities, not its core insurance operations. AIG's financial products group placed large, unhedged bets that housing prices would not fall by selling credit default swaps. AIG's risk models showed that the risk of defaults affecting super senior tranches of collateralized debt obligations on which many of the credit default swaps were written was nil. The models didn't consider how collateral calls and related demands for cash could escalate in the face of increases in

\footnotetext{
${ }^{2}$ Congressional Oversight Panel, The AIG Rescue, Its Impact on Markets, and the Government's Exit Strategy, June 10, 2010, which provides a comprehensive review of AIG's problems and bailout. Also see my paper referenced in note 1.
} 
subprime defaults - or, apparently, how sensitive the market value of AIG's positions was to moderate changes in the expected default rate on subprime mortgages.

Apart from AIG (and specialty mortgage/bond insurers, see below), the insurance sector withstood the crisis reasonably well. General property/casualty insurers and most life and health insurers avoided severe adverse consequences. AIG's property/casualty subsidiaries appeared reasonably well capitalized at the time of the bailout. Several large life insurers experienced financial stress and rating downgrades in conjunction with long-term investments in mortgages, other fixed income securities, and common equities to fund asset accumulation products, including contracts with minimum return guarantees. Several insurers sought and received regulatory permission in some states to modify financial reporting to improve their reported capital. In addition to AIG, six insurers applied for and were authorized to receive Troubled Asset Recovery Program (TARP) funds. Four of them (Allstate, Ameriprise Financial, Principal Financial, and Prudential Financial) declined to receive funds. Hartford Financial received \$3.4 billion; Lincoln Financial \$950 million. Met Life declined to seek TARP funding. Genworth Financial applied for funding but was denied.

Leading mortgage and bond insurers experienced significant losses and highly publicized downgrades by financial rating agencies. Insurance law and regulation mandate a monoline structure for such insurers and require substantial contingency reserves. This regulatory framework apparently helped prevent their problems from spilling over to other lines of insurance, in contrast to what occurred in commercial and investment banking.

AIG's credit default swap activities were not conducted by regulated insurance subsidiaries. State regulators commenced steps to reduce AIG's exposure from securities lending in 2007. Treasury and Federal Reserve officials initially justified the bailout as necessary to protect AIG's banking and securities counterparties and prevent collapse of the financial system. They later argued that the bailout was justified in significant part to protect AIG's policyholders and prevent runs on AIG's insurance subsidiaries. However, despite AIG's credit default swaps, securities lending, exposure of other investments to mortgage defaults, and high leverage at the holding company level, it remains uncertain that any of its insurance subsidiaries would have become insolvent if the government had not intervened. 
As a consequence of owning a savings and loan subsidiary, AIG was subject to consolidated regulation and oversight by the U.S. Office of Thrift Supervision (OTS), and it was recognized as such for the purpose of meeting the 2005 E.U. regulatory criterion for group supervision. The OTS, which was eliminated by the Dodd-Frank Act, was also responsible for regulating several large mortgage finance organizations that eventually failed and were merged with or acquired by other entities with Federal Deposit insurance Corporation (FDIC) assistance.

There is substantial evidence that the financial crisis reflected fundamental failures in U.S. and foreign banking regulation, including in the U.S. by the OTS, the Office of the Comptroller of the Currency (the regulator of federally chartered commercial banks), the FDIC, the U.S. Securities and Exchange Commission (SEC), and the Federal Reserve. Banking regulation permitted high leverage, aggressive investment strategies, inadequate capital requirements for risky loans and securitizations, and complex offbalance sheet vehicles, often financed by commercial paper. Many of AIG's major counterparties were regulated by U.S. and foreign banking regulators. Because broad regulatory authority encompasses responsibility for monitoring an institution's relationships with counterparties that could allow it to take on excessive risk, federal banking regulators also bear significant responsibility for not recognizing the risks of allowing regulated banking entities to (1) buy extensive amounts of credit protection from AIG, and (2) provide large amounts of securities lending collateral to AIG.

\section{Systemic Risk: Insurance vs. Banking}

Although there is no uniform definition, the term "systemic risk" generally is used broadly to encompass the risk of any large, macroeconomic shock and the risk arising from extensive interdependencies or "interconnectedness" among firms, with an attendant risk of contagion and significant economic spillovers. There is a distinction, however, between the risk of common shocks to the economy, such as widespread reductions in housing prices or large changes in interest rates or foreign exchange, which have the potential to directly harm large numbers of people and firms, and financial risk that arises from interconnectedness and contagion. Evidence of the effects of such shocks on a few firms may lead to reevaluation and information that other firms have also been directly affected (e.g., recognition of asset 
problems at one institution leads to recognition of similar problems at other institutions). If so, delayed recognition of the effects of a common shock might sometimes give the appearance of contagion.

The economics literature has identified four sources of potential contagion that could contribute to systemic risk, including: (1) asset price contagion, where a shock causes one or more financial institutions to have to sell large amounts of assets at temporarily depressed prices ("fire sales"), thereby further depressing prices and market values of institutions that hold similar assets; (2) counterparty contagion, where shocks to some firms make them unable to honor commitments to counterparties, thereby causing some of the counterparties to likewise default on their commitments, with repercussions that cascade through financial markets; (3) information-based contagion, where the revelation of financial problems at some institutions creates uncertainty about the effects on counterparties and whether other institutions face similar problems, so that parties become reluctant to trade until further information becomes available; and (4) irrational contagion, where investors and/or customers withdraw funds without regard to whether specific institutions are at risk.

The events at AIG and general financial crisis coincided with bursting of the housing price bubble and attendant increases in actual and expected mortgage defaults, which greatly reduced the values of mortgage-related securities as the new information was reflected in prices. While there were elements of counterparty contagion, asset price contagion, and uncertainty/opacity contagion, the principal problem was the decline in security values. Whether AIG's credit default swaps and securities lending presented significant risk of contagion remains uncertain, including the extent to which an AIG bankruptcy would have had significant adverse effects beyond its counterparties, or the extent to which its counterparties had hedged their exposure to AIG or otherwise reduced their risk. A failure to rescue AIG and channel $\$ 100$ billion of government assistance to its counterparties would have weakened their financial condition, which could have forced at least some to sell more assets and reduced their ability to invest, trade and/or make loans. Some of AIG's E.U. banking counterparties would have needed to raise more capital or significantly reduce their risk exposure. Without federal intervention, many more of AIG's insurance customers might 
have terminated or declined to renew their policies, but that by itself would not imply contagion, or that those customers would be harmed financially.

AIG notwithstanding, the consensus is that systemic risk is relatively low in insurance markets compared with banking, especially for property/casualty insurance, in part because many insurers hold greater amounts of capital in relation to their liabilities, reducing their vulnerability to shocks. ${ }^{3}$ Systemic risk is generally regarded as larger for life insurers than for property/casualty insurers, given their higher leverage and greater liquidity risk. Even then, shocks to life insurers do not threaten the economy's payment system and short-term lending, as is true for commercial banks. Banking crises have much greater potential to produce rapid and widespread harm to economic activity and employment.

Differences in systemic risk among insurers and banks help explain historical differences in regulation across sectors. Other things being equal, greater systemic risk favors stronger government guarantees of financial institutions' obligations to protect consumers and help reduce systemic risk by deterring runs, as well as more stringent capital requirements. The issues are related. Stronger guarantees increase moral hazard: they reduce market discipline for financial institutions to be safe and sound, increasing the need for more stringent capital rules. Thus, systemic risk favors relatively broad government guarantees of bank obligations and relatively stricter financial regulation, including capital

\footnotetext{
${ }^{3}$ J. Santos, 1999, Bank Capital Regulation in Contemporary Banking Theory: A Review of the Literature, BIS Working Paper No. 90, explains why systemic risk is generally lower for all non-bank financial institutions than for banks. R. Nebel, 2001, The Case for Liberal Reinsurance Regulation, Swiss Re, provides a useful discussion of why systemic risk is low for insurance. Also see my chapter, Capital Adequacy in Insurance and Reinsurance, in: H. Scott, ed., Capital Adequacy Beyond Basel: Banking, Securities, and Insurance (Oxford University Press, 2004). For detailed treatments in the context of the financial crisis, see Systemic Risk in Insurance - An analysis of Insurance and Financial Stability, Special Report of The Geneva Association Systemic Risk Working Group, March 2010; and J.D. Cummins and M. Weiss, Systemic Risk and the U.S. Insurance Sector, Temple University, September 14, 2010. The latter paper argues that while the core activities of U.S. insurers do not pose systemic risk, both life and property/casualty insurers may be vulnerable to intra-sector crises from reinsurance arrangements and that life insurers may be vulnerable to leverage and liquidity risk. Several papers by V. Acharya and colleagues (e.g., On the Financial Regulation of Insurance Companies, NYU Stern School of Business, August 2009) argue that quantitative metrics that reflect insurer stock returns in down markets imply that some insurers (AIG and several life insurers) have systemic risk levels comparable to major banks.
} 
requirements. Strict capital requirements in turn increase incentives for banks to evade the requirements.

Because insurance, especially property/casualty insurance, poses much less systemic risk, there is less need for strict capital requirements and relatively broad guarantees to prevent runs that would destabilize the economy. Insurance guarantees have been narrower in scope than in banking, and, as is elaborated below, market discipline is reasonably strong. Insurers commonly have held much more capital than required by regulation and have not faced incentives for regulatory arbitrage and other evasion.

\section{The FSOC and Systemic Risk Regulation}

The FSOC is charged with (1) identifying risks to financial stability from "the material financial distress of large, interconnected bank holding companies or nonbank financial companies, or that could arise outside the financial services marketplace"; (2) promoting market discipline "by eliminating expectations on the part of shareholders, creditors, and counterparties that the Government will shield them from losses in the event of failure"; and (3) responding to "emerging threats to the stability of the U.S. financial system." The FSOC consists of 10 voting members from "Member Agencies" (including, among others, the Federal Reserve Chair, Treasury Secretary, SEC Chair, FDIC Chair, Comptroller of the Currency, and a presidential appointee with expertise in insurance) and five non-voting members, including the director of the Office of Financial Research, Director of the FIO, a state insurance commissioner, a state banking commissioner, and a state securities commissioner.

When complete, the FSOC will thus have three members with insurance expertise: a presidential appointee, the FIO Director, and a state insurance commissioner. As of March 9, 2011, neither the presidential appointee nor the FIO Director had been named. The Dodd Frank Act also established the Office of Financial Research within Treasury to provide support to the FSOC through data collection, data standardization, long-term research, and development of risk measurement and monitoring metrics. The Director, to be appointed by the President, will have a six year term.

Section 113 of the Dodd-Frank Act gives the FSOC the authority by a two thirds vote to designate a nonbank financial company, including an insurance company, as systemically 
important and subject to enhanced regulation and supervision by the Federal Reserve. The Federal Reserve is required to establish, with input from the FSOC, enhanced risk-based capital requirements, leverage rules, resolution standards, and other requirements for systemically important companies. Section 113 specifies factors the FSOC must consider in determining whether a company will be subject to enhanced supervision including its leverage; off-balance sheet exposure; importance as a source of credit and liquidity for households, businesses, state and local governments, and low-income communities; the nature, scope, size, and interconnectedness of its activities; the amounts and nature of its assets and liabilities; the degree to which it is already regulated by one or more primary regulators; and "any other riskrelated factors that the Council deems appropriate."

In October, 2010, the FSOC issued an Advanced Notice of Rulemaking regarding designation of nonbank financial companies as systemically important under Section 113. After receiving comments by interested parties, the FSOC issued a Notice of Proposed Rulemaking in January, 2011. Section III (Overview of Proposed Rule), Part B (Statutory and Analytical Framework for Designations) indicates that the proposed framework for determining systemically important companies is organized around six broad categories:

1. Size;

2. Lack of substitutes for the financial services and products the company provides;

3. Interconnectedness with other financial firms;

4. Leverage;

5. Liquidity risk and maturity mismatch; and

6. Existing regulatory scrutiny.

Section III.B explains that the size, lack of substitutes, and interconnectedness criteria "seek to assess the potential for spillovers from the firm's distress to the broader financial system." The leverage, liquidity / maturity mismatch, and existing regulatory scrutiny criteria "seek to assess how vulnerable a company is to financial distress." The text of the overview also indicates that the Council "expects to use its judgment, informed by data on the six categories, to determine whether a firm should be designated as systemically important and supervised by the Board of Governors," and it provides a table linking the statutory factors to the six categories. However, the text of the proposed rule itself lists only the statutory factors: it contains no discussion of the six broad categories or their implementation. 
Several insurance trade associations have taken issue with one or more aspects of the FSOC's Notice. Objections include the proposed rule's lack of specificity and the exclusion of the discussion of the proposed framework from the rule itself. There is also concern that firm size might be weighed too heavily, without regard to other factors that could make systemic risk negligible despite a firm's large size. Trade groups have also criticized promulgation of the Notice without appointment and participation of the FIO Director and Presidential appointee with insurance expertise. The NAIC's president has expressed concern that the insurance commissioner appointed to the FSOC has been prevented from seeking relevant input from the NAIC and state regulators. ${ }^{4}$

\section{Assessment}

The large U.S. investment banks that survived the financial crisis became bank holding companies and are, therefore, regulated by the Federal Reserve, with enhanced supervision required by the Dodd-Frank Act (based on their size). AIG remains under the effective control of the Treasury and the Federal Reserve, mooting its regulatory status. I explained in a 2009 paper (see note 1) why I regard as bad policy the possible creation of a systemic risk regulator with authority to designate individual insurers and other nonbank financial companies as systemically significant and subject to comprehensive regulation and oversight by the Federal Reserve or other federal agency. The reasons include:

1. Greater capital requirements and tighter regulation for individual companies designated as systemically important raises the risk that they could face excessive burdens and costs that would disrupt competition and harm customers.

2. The possibility of being designated as systemically important and subject to more stringent federal regulation creates significant uncertainty for large, non-bank financial companies that could likewise distort their financial and operating decisions in undesirable ways.

3. Regardless of assertions that creditors and shareholders of companies designated as systemically important will not be bailed out in the event of financial distress, there is

\footnotetext{
${ }^{4}$ See A. Postal, NAIC President: State Regulators Shut Out of FSOC Participation, National Underwriter 360, March 2, 2011. http://www.propertycasualty360.com/2011/03/02/naicpresident-state-regulators-shut-out-of-fsoc-p.
} 
nonetheless a nontrivial risk that bailouts would be anticipated, which could ultimately worsen moral hazard and the "too big to fail" problem. ${ }^{5}$

4. Given the failure of regulators (and professionals) to anticipate the financial crisis, there can be little confidence that "enhanced" supervision of companies designated as systemically important will significantly reduce the likelihood of a future crisis.

These complaints notwithstanding and as highlighted above, strong arguments can be made that the core activities of large property/casualty insurers do not pose systemic risk. Reasonable application by the FSOC of the statutory criteria and/or six categories of factors in the Notice should not result in designation of any companies that predominantly write property/casualty insurance as systemically important. Although some large life insurers may pose greater systemic risk than property/casualty insurers, reasonable application of the criteria should also exclude most if not all life insurers from designation as systemically important. If any property/casualty or life insurers are designated as systemically important and subject to enhanced regulation by the Federal Reserve, the competitive dynamics of the insurance market will be affected in unpredictable ways.

It is desirable to the extent practical for the FSOC to present clear criteria for determining whether a nonbank financial company would likely be regarded as systemically important. Transparency of criteria and procedures will reduce the risk and uncertainty associated with such determinations and allow companies to take actions to reduce their risk so as not to be subject to additional regulation. In addition to their statutory rights to appeal such determination, companies should be allowed an opportunity to present evidence to the FSOC before they are deemed systemically important.

\section{The FIO and its Report to Congress}

Title V of the Dodd-Frank Act established the FIO within the Department of Treasury with a Director appointed by the Treasury Secretary. The FIO will monitor the insurance industry, including assessment of potential gaps in regulation that could contribute to systemic

\footnotetext{
${ }^{5}$ As an example of this view, R. Hubbard, H. Scott, and J. Thornton, The Fed Can Lead on Financial Supervision, Wall Street Journal, July 24, 2009, A13, write: "Identifying an institution as systemically important creates a moral hazard, since the market will view this designation as the equivalent of a bailout guarantee. A perceived bailout guarantee will decrease these institutions' costs of raising capital."
} 
risk; recommend to the FSOC insurers that should be considered systemically important; represent the U.S. in the International Association of Insurance Supervisors (IAIS); negotiate international agreements on insurance supervision; assist in administration of the Terrorism Risk and Insurance Program; and monitor whether underserved communities, minorities, or low-income people have access to affordable insurance. The statute provides the FIO with powers to collect information from insurers, including subpoena authority. The FIO has the authority to preempt state insurance regulation that is inconsistent with any international prudential regulation agreement that discriminates against a non-U.S. insurer compared with a U.S. insurer (after consultation with the state's regulators). Preemption cannot involve state regulations dealing with rates, premiums, underwriting, sales practices, coverage requirements, or antitrust law.

The statute requires the FIO to study and report to Congress on the regulation of insurance within 18 months of enactment. The required study and report must address a comprehensive set of issues including:

- Systemic risk and capital requirements;

- The degree of national uniformity of state regulation;

- Regulation of insurance companies and affiliates on a consolidated basis;

- International coordination of insurance regulation;

- The costs and benefits of federal regulation for different lines of insurance (except health insurance) and feasibility of regulating only certain lines at the federal level; and

- The potential consequences of subjecting insurance companies to federal resolution authority, including the effects on the operation of state insurance guaranty funds.

The analysis and report will thus in part address state versus federal regulation and possible optional federal chartering for some or all lines of insurance. The results could have far reaching effects on the structure and locus of insurance regulation. The following discussion sets forth factors that I believe the FIO should consider in five areas: (1) Modernizing regulation, (2) promoting market discipline, (3) policyholder guarantees, (4) capital requirements, and (5) group supervision. An overall theme is that the FIO should consider how fundamental differences between banking and insurance favor regulatory systems that reflect the distinctive characteristics of each sector. 


\section{Modernizing Regulation}

The possible creation of a system of optional federal chartering and regulation for insurance companies has been debated for at least two decades. Pre-crisis pressure for optional federal chartering or other fundamental changes in state insurance regulation focused on the costs and delays of regulatory approval of policy forms in over 50 different jurisdictions; the costs, delays, and possible short-run suppression of rates below insurers' projected costs associated with prior regulatory approval of insurers' rate changes; and restrictions on insurers' underwriting and risk classification. ${ }^{6}$ The pricing and underwriting issues were primarily relevant for property/casualty insurers. Regulation of policy forms was the overriding issue for life insurers. Optional federal chartering was often viewed as a potential mechanism for achieving desirable regulatory modernization with suitable deregulation, including improved ability to deal with multi-jurisdictional issues within the U.S. and internationally.

The traditional arguments against optional federal chartering of insurers include: (1) the states have performed reasonably well on many dimensions, including regulating solvency and analyzing and revising regulation to deal with perceived problems (including, for example, the current Solvency Modernization Initiative); (2) optional federal chartering could create an unequal playing field between large multistate insurers and small insurers that are reasonably satisfied with state regulation and would face relatively high costs of switching charters; and, more broadly, (3) the potential risks and costs of optional federal chartering are large compared with the uncertain benefits.

The history of federal deposit insurance and "too big to fail" policy creates some risk that optional federal chartering could expand government guarantees of insurers' obligations, undermining market discipline and incentives for safety and soundness, and increasing the likelihood of future federal bailouts of insurance companies. Even if optional federal

\footnotetext{
${ }^{6}$ I provided details in my paper for the $2^{\text {nd }}$ Annual Insurance Reform Summit, Federal Chartering of Insurance Companies: Options and Alternatives for Transforming Insurance Regulation, Networks Financial Institute Policy Brief, 2006-PB-02, March 2006. In contrast to the early 1970s and early 1990s, when temporary increases in the frequency and severity of insurance company insolvencies motivated optional federal chartering proposals, pressure optional federal chartering during from the late 1990s until the crisis was not primarily motivated by solvency concerns.
} 
chartering were to reduce the scope of insurance price regulation initially, it could ultimately produce broad restrictions on pricing and underwriting at the federal level to achieve political or social goals (as has been illustrated by the health insurance rate review and minimum medical loss ratio requirements in the health care reform law enacted in 2010). Such restrictions would increase cross-subsidies among policyholders, inefficiently distort some policyholders' incentives to reduce the risk of loss, and increase risk to federal taxpayers if political pressure led to inadequate rates. Alternatives to optional federal chartering that might have the potential for improving insurance regulation with less risk include: (1) selective federal preemption of inefficient state regulations, such as prior approval rate regulation in competitive markets and inefficient impediments to nationwide approval of certain products, and (2) allowing insurers to choose a state for primary regulation with authorization to operate nationwide primarily under the rules of that state.

Some observers have since asserted that the AIG collapse and bailout support optional federal chartering and possibly mandatory federal chartering for systemically significant insurers. If the federal government may have to intervene in the event that a large and systemically significant financial institution with extensive insurance operations becomes financially distressed, it has been argued that it should have regulatory authority over such institutions ex ante, and that smaller and/or less systemically significant competitors should have the option to choose federal regulation.

Some arguments against federal regulation of individual insurers designated as systemically significant were discussed above. It also is not clear how the financial crisis has fundamentally altered the potential benefits and costs of optional federal chartering. AIG's problems cannot be primarily attributed to any insurance regulatory failure. While disputed and subject to some uncertainty, it appears that AIG would likely have been able to largely or completely meet its obligations to policyholders without federal intervention, with state insurance guaranty funds serving as a potentially important back up if it could not. The alternative scenario - where insolvency of AIG subsidiaries had required multi-billion dollar assessments under the state guaranty system - might have strengthened the argument for federal regulation. Even then, however, a strong case for federal regulation in response to the crisis would need to explain how federal insurance regulation before the crisis would 
have prevented or mitigated AIG's problems. That would not be easy in view of what happened at major bank and investment bank holding companies. There can be no presumption that federal regulation of AIG's insurance operations would have prevented or mitigated risk taking at AIG, or that optional federal chartering with or without mandatory federal chartering for large insurance organizations would mitigate any role of insurance in some future financial crisis.

\section{Promoting Market Discipline}

Regulatory failures notwithstanding, a lack of market discipline represents a key underlying cause of the financial crisis. A simple explanation for much of the aggressive risk taking by commercial banks, investment banks, savings and loans, mortgage originators, and subprime borrowers was that the potential gains and losses were asymmetric. If housing prices continued upwards, or at least didn't fall, participants could achieve large profits. If housing prices stabilized, or even fell, the losses would be borne largely by other parties, including taxpayers. The extended period of historically low interest rates further encouraged high leverage and fueled risky borrowing, lending, and investment.

A primary objective of additional legislative, regulatory, and administrative responses to the financial crisis should be to encourage market discipline to promote safety and soundness in all types of financial institutions. A key, stated objective of the Dodd-Frank Act is to reduce the likelihood of future bailouts of financial institutions. Whether the Act is likely to achieve that goal is uncertain and heavily debated. But an overriding goal of implementing the Act and of any future changes in financial regulation should be to constrain too big to fail policy. As noted above, a potential downside to FSOC designation of an insurer as systemically important and subject to regulation by the Federal Reserve is that it ultimately could undermine market discipline if creditors, counterparties, investors, and/or consumers anticipate additional protection against the consequences of the insurer's financial distress.

The FIO analysis should also consider that insurance markets generally have been characterized by relatively strong market discipline and correspondingly low insolvency risk. ${ }^{7}$

\footnotetext{
${ }^{7}$ I discussed this issue in detail in my paper, Market Discipline in Insurance and Reinsurance, in Market Discipline: The Evidence Across Countries and Industries, C. Borio, et al., eds. (MIT Press, 2004).
} 
Many if not most policyholders prefer to deal with financial strong insurers and are willing to pay the higher costs that greater financial strength require (even with limited state guarantees, see below). A variety of institutions, including the widespread use of insurance intermediaries (agents, brokers, advisors), private ratings of insurers' financial strength, and, for business coverages, knowledgeable corporate staff who oversee risk management and insurance programs, help match risk sensitive policyholders with financially strong insurers. In addition, insurance production and distribution often involve the creation of sizable franchise value, which could diminish or evaporate if an insurer experiences financial distress. Protection of those assets from loss due to financial difficulty therefore provides a significant incentive for adequate capitalization and other forms of risk management by insurers. Finally, many insurers in the U.S. issue debt, primarily at the holding company level. Until the AIG bailout, that debt was effectively subordinated to policyholder claims, creating an additional category of stakeholders concerned with risk management.

\section{Policyholder Guarantees}

Given the importance and scope of existing market discipline, the FIO should recognize the fundamental importance of avoiding any significant expansion of government guarantees of insurers' obligations and carefully consider the potential effects of possible federal regulation on the state guaranty system. In contrast to "too big to fail" policy, and consistent with lower systemic risk in insurance than in banking, protection provided by state guaranty funds is relatively narrow, which reduces moral hazard and preserves market discipline.

While the FIO will likely be confronted with arguments that the state system of ex post funding of guarantees is defective, that system has several advantages. Coupled with potential borrowing by state guaranty associations, pre-funding is not necessary for the system to have substantial capacity. Ex post funding helps provide incentives for financially strong insurers to press for effective regulatory oversight, and it has avoided accumulating funds that could tempt budget-constrained legislators.

Some academics take it as given that pre-funding of guarantees would be preferable, in large part because they believe it would permit insurers to be charged accurate, risk-based premiums for guaranty protection, thus encouraging incentives for financial soundness. That 
view is nice in theory, but it cannot be reconciled with practice, where premiums will likely be based only crudely on risk, if at all. It's likely that the adoption of pre-funded guarantees would yield its disadvantages without enough risk-rating to significantly improve incentives. It's also worth noting that the Dodd-Frank Act adopted ex post funding of the Orderly Liquidation Fund to repay possible borrowings from the Treasury by the FDIC, via "postevent" assessments on bank holding companies with $\$ 50$ billion or more in assets and any nonbank financial companies designated as systemically important (with graduated assessments to be proposed by the FSOC based on assets, risk, and other factors).

Given that federal guarantees would likely be viewed by policyholders as stronger than state guarantees, a federal guaranty system for federally chartered insurers in a system of optional federal chartering might soon supplant state guarantees - so that most or even all insurers would end up being backed by a federal guaranty. As an alternative (and as has been previously proposed), federally chartered insurers could be required to participate in the state guaranty system. The FIO should consider, however, the long-run stability of such a system. If an insurer operating in multiple states failed, there would likely be substantial criticism of any state differences in guaranty coverage. Failure of a state chartered insurerwith federally chartered insurers having to contribute - could likewise lead to substantial criticism of state guarantees and solvency oversight. A possible belief that the federal government would stand behind federally chartered insurers (perhaps especially any insurer designated as systemically important) would distort competition between state and federally chartered insurers, especially if any insurer were designated as "systemically significant."

As a result, substantial pressure for federal guarantees could be inevitable with optional federal chartering, perhaps by designing federal guarantees along the lines of existing state guarantees. The design of any government guarantees also might be tailored in principle to help encourage additional market discipline. It should be recognized from the outset, however, that a monopoly federal guaranty program might ultimately ensue with optional federal regulation. That result could undermine market discipline, requiring tougher capital requirements and regulation. 


\section{Capital Requirements}

The FIO's analysis of capital requirements will likely evaluate the adequacy and effectiveness of the NAIC risk-based capital system and possible alternatives, such as capital standards under the Solvency II regime that will be implemented in the E.U. in 2012.

Solvency II requires that non-E.U. countries insurance regulatory systems meet certain criteria in order for their capital, group, and reinsurance standards to be deemed equivalent to those of the E.U. If deemed equivalent, E.U. supervisors will rely on the country's supervision and treat insurers and reinsurers from that country the same as E.U. insurers and reinsurers. In November, 2010, Deputy Treasury Secretary Neal Wolin indicated that Treasury expects that the FIO will be "actively involved" in international consultations regarding U.S. equivalence under Solvency II. ${ }^{8}$

Solvency II's capital standards are embedded in a "three pillar" approach to solvency supervision that mimics the approach in the Basel II accords on bank supervision: ${ }^{9}$

- Pillar 1: Quantitative requirements, including minimum capital and risk-based "solvency" capital. The solvency capital requirement includes a "standard approach" (capital model) and, alternatively, permits required capital to be based on a firm's approved internal capital model if approved by regulators.

- Pillar 2: Supervisory review, including review of a firm's internal risk management capabilities and qualitative assessment of the firm's risk and capital, with the possibility of requiring the firm to hold additional capital.

- Pillar 3: Market discipline, including required public disclosure of relevant measures of the firm's risk.

In contrast to the U.S. risk-based capital system, the Solvency II's quantitative requirements involve calculation of quantitative (stochastic) risk models. The standard capital model, for example, will employ a $99.5 \%$ value at risk metric for a one-year horizon in determining required capital. Moreover, and again borrowing from the bank regulatory model of Basel II, the Solvency II approach is principles-based rather than rules-based in that

\footnotetext{
${ }^{8}$ M. Hoffman, Federal Insurance Office Seeks International Cooperation, Business Insurance, November 17, 2010. http://www.businessinsurance.com/article/20101117/NEWS/101119943.

${ }^{9}$ See J.D. Cummins and R. Phillips, Capital Adequacy and Insurance Risk-Based Capital Systems, Journal of Insurance Regulation 28 (Fall 2009): 25-72, for an overview of Solvency II capital standards and comparison to the U.S. and Swiss systems.
} 
it will provide a firm with the opportunity to convince regulators that it needs less capital based on its own (internal) model. The FIO will likely consider whether such an approach is desirable in the United States.

As part of its Solvency Modernization Initiative, the NAIC is considering changes to its risk-based capital system that currently appear likely to retain the same basic structure. The NAIC risk-based capital standards have been criticized on a variety of dimensions. It is often argued that the types of risk reflected, the risk-weights, and the aggregation methods are ad hoc and unnecessarily crude, especially compared with more sophisticated quantitative risk models. Those criticisms will likely be considered by the FIO.

It is not clear, however, that more sophisticated quantitative models to derive "value at risk" (or "tail value at risk") are more appropriate for achieving the objectives of insurance capital regulation. It almost always can be argued that capital standards, even those based on relatively complex formulas, are not rigorous enough and that additional refinements and sophistication are warranted. While seemingly precise, the results of mathematically sophisticated risk models need not be accurate. Their potential value in analyzing a firm's risk need not imply that they should provide the foundation for regulatory capital.

Some observers suggest that the relatively low levels of total risk-based capital compared to total insurance industry capital indicate that the NAIC risk-based capital formulas do not require sufficient capital. The FIO should consider, however, that relatively low levels of risk-based capital in relation to actual capital for the bulk of insurers are advantageous given the degree of market discipline in insurance. ${ }^{10}$ No matter how sophisticated, regulatory capital standards can produce undesirable distortions in the

\footnotetext{
${ }^{10} \mathrm{I}$ considered this issue in detail in my 2004 paper referenced in note 3.
} 
decisions of financially sound insurers. Current risk-based capital standards in the U.S. have relatively little effect on the operating and financial decisions of financially strong insurers, which hold far more capital than required by the standards. Even with refinements of risk measures or changes in the basic modeling framework to improve accuracy, any significant increase in the overall level of risk-based capital could lead to undesirable distortions in decisions of many financially sound insurers. The effects could include reduced willingness to provide coverage, less efficient investment strategies, and/or higher prices, especially following any large, negative shocks to insurer capital.

Overall, the financial crisis, bank capital models, and Solvency II do not imply the need for fundamental changes in U.S. insurance company capital requirements. Insurance capital requirements in the U.S. should continue to recognize the distinctive nature of U.S. insurance markets. Systemic risk in banking has encouraged relatively broad guarantees and capital requirements that constrain risk-taking by many institutions, in part to reduce moral hazard. Binding capital requirements generate pressure from banks to relax requirements and/or to make the requirements more accurate, including by allowing the use of internal models. Insurance is different, especially property/casualty insurance. There is much less systemic risk and thus need for stringent capital requirements combined with relatively broad guarantees of firm's obligations. Relatively strong market discipline favors capital requirements that generally are easily met by the bulk of insurance companies, reducing potential undesirable distortions of sound companies' operating decisions and incentives for evading the requirements. Less constraining capital requirements make attempts at precision less important.

\section{Group Supervision}

State regulation has generally focused on individual insurers, in contrast with insurance regulation in non-U.S. jurisdictions and U.S. banking regulation, which focus more attention on consolidated supervision. A certain degree of coordination in insurance solvency regulation is achieved through deference to regulators in an insurer's state of domicile (or lead domiciliary regulator in the case of multiple domiciles) and coordinated analysis and dissemination of financial metrics for larger, multistate insurers. State regulators and the NAIC have also relied on an elaborate statutory and administrative framework to deter parent holding companies 
that experience financial difficulty from draining funds or otherwise undermining the solvency of insurance subsidiaries.

Solvency II requires groupwide supervision of E.U. insurance entities and, as noted above, "equivalent" supervision of non-E.U. parents of E.U. entities. In 2009 the International Monetary Fund's Financial Sector Assessment Program recommended that U.S. regulators expand assessments of individual insurers to the group level. The NAIC is working on revisions to its model holding company acts dealing with relationships between parents and state-licensed subsidiaries. It also is exploring enhanced methods for information sharing regarding holding company risk and solvency and the possibility of developing group-wide capital standards. Similar to Solvency II, the NAIC is considering requiring groups to conduct and provide regulators with "Own Risk Solvency Assessments" of their risks, capital needs, and capital adequacy on a consolidated basis.

The NAIC is also considering modes of participation of state regulators in "supervisory colleges" of regulators from different countries to share information about internationally active insurance groups, and it is working with the IAIS on an initiative for developing a system of collaborative supervision of such groups. Known as ComFrame (Common Framework for the Supervision of Internationally Active Insurance Groups), this initiative is designed to enhance oversight with greater consistency and coordination, including through designation of a group-wide supervisor to take the lead on oversight and participation in a supervisory college of regulators from relevant jurisdictions.

The FIO's study of the regulation of insurance companies and affiliates on a consolidated basis should carefully consider these efforts at greater coordination among state and national insurance regulators. The FIO should consult extensively with the NAIC and the IAIS. A key goal should be to understand and assess the potential benefits of collaborative frameworks for multijurisdictional supervision that do not rely on federal insurance regulation in the U.S. in comparison with systems that would provide a greater role for federal regulation.

\section{Conclusion}

Despite some convergence, U.S. financial institutions can be expected to specialize predominantly in either banking (and/or securities) or insurance for the foreseeable future. 
Insurance has fundamental differences from banking, including much lower potential for systemic risk. The inherent differences between banking and insurance favor regulatory and guaranty frameworks that reflect the distinctive features of each sector. The FSOC and FIO should carefully consider those differences in their analyses of possibly systemically important insurance companies and in the FIO's study and report to Congress on insurance regulation. Particular attention should be paid to the relatively low systemic risk and relatively strong market discipline in insurance compared with banking. 


\section{References}

Acharya, Viral V., John Biggs, Matthew Richardson and Stephen Ryan. 2009. On the Financial Regulation of Insurance Companies. New York University Stern School of Business White Paper. August. http://w4.stern.nyu.edu/salomon/docs/whitepaper.pdf.

Borio, Claudio, William Curt Hunter, George Kaufman and Kostas Tsatsaronis, eds. 2004. Market Discipline in Insurance and Reinsurance, in Market Discipline: The Evidence Across Countries and Industries. MIT Press.

Congressional Oversight Panel. 2010. The AIG Rescue, Its Impact on Markets, and the Government's Exit Strategy. June 10. http://cop.senate.gov/documents/cop-061010report.pdf.

Cummins, J. David and Richard D. Phillips. 2009. Capital Adequacy and Insurance Risk-Based Capital Systems, Journal of Insurance Regulation 28, 25-72.

Cummins, J. David and Mary A. Weiss. 2010. Systemic Risk and the U.S. Insurance Sector, Temple University, September 14.

Geneva Association. 2010. Systemic Risk in Insurance - An Analysis of Insurance and Financial Stability, Special Report of The Geneva Association Systemic Risk Working Group, March. http://www.genevaassociation.org/PDF/BookandMonographs/Geneva Association Systemi c Risk in Insurance Report March2010.pdf.

Harrington, Scott E., Ed. 2004. Capital Adequacy in Insurance and Reinsurance in Capital Adequacy Beyond Basel: Banking, Securities, and Insurance. Oxford University Press.

Harrington, Scott E. 2006. Federal Chartering of Insurance Companies: Options and Alternatives for Transforming Insurance Regulation. Networks Financial Institute Policy Brief 2006-PB-02. March.

Harrington, Scott E. 2009. The Financial Crisis, Systematic Risk, and the Future of Insurance Regulation. Journal of Risk and Insurance, 76, 785-819. December.

Hoffman, Mark. 2010. "Federal Insurance Office Seeks International Cooperation." Business Insurance, November 17. http://www.businessinsurance.com/article/20101117/NEWS/101119943.

Hubbard, R. Glenn, Hal Scott and John Thornton. 2009. The Fed Can Lead on Financial Supervision. Wall Street Journal. July 24. http://online.wsj.com/article/SB10001424052970203946904574300391846855688.html

Nebel, Rolf. 2002. The Case for Liberal Reinsurance Regulation. The Geneva Papers on Risk and Insurance 27, 113-121. January.

Postal, Arthur. 2011. "NAIC President: State Regulators Shut Out of FSOC Participation." National Underwriter 360. March 2. http://www.propertycasualty360.com/2011/03/02/naicpresident-state-regulators-shut-out-of-fsoc-p.

Santos, João. 2000. Bank Capital Regulation in Contemporary Banking Theory: A Review of the Literature, Bank for International Settlements Working Paper No. 90. September. 